Seminar Nasional Teknologi Informasi dan Kedirgantaraan (SENATIK)

Vol. II, 26 November 2016, ISSN: 2528-1666

\title{
Membangun Cloud Computing Memanfaatkan Google Drive untuk Meningkatkan Layanan Akademik
}

\author{
Hero Wintolo, Derry Purnamasari \\ Program Studi Teknik Informatika Sekolah Tinggi Teknologi Adisutjipto Yogyakarta \\ Email: herowintolo@stta.ac.id
}

\begin{abstract}
As one of the products of google, google drive software can be worn and used by computer users who have access to the Internet by using a gmail account. With this account also users of android based smartphone which is also a product of google google drive can access using the equipment. The easier and cheapness of the equipment that is used as cloud computing services to support the academy. This service is an application of academic information used by parents of students to access academic information in the form of academic data. The main source of data from a web server and is designed to upload data automatically academic on google drive, so that data can be read by users who have android smartphone. Academic data that can be seen in the form of pdf format. The software that is made is also tested by utilizing a user who has access to the service academies. The test results showed that the existing data on google drive in accordance with the student registration number is entered and accessed on android smartphone and a value is given using questionnaires and calculated the Likert method was $81.57 \%$.
\end{abstract}

Keywords: Cloud Computing, Google Drive, cloud storage, Android Smartphone

\section{Pendahuluan}

Perkembangan informasi dan teknologi telah mengalami percepatan yang tinggi, terlebih lagi perkembangan media terjadi begitu pesat dengan memanfaatkan internet yang membuat akses informasi begitu penting adanya. Keadaan tersebut membuat banyak hal dapat dilakukan dengan lebih mudah dan efisien. Berbagai akses informasi telah banyak berevolusi dan memberi manfaat yang besar dalam berbagai aspek, salah satunya pada bidang akademik. Akses informasi akademik bukan hanya dibutuhkan oleh mahasiswa atau pelajar saja, namun juga dibutuhkan oleh orang tua/wali guna memantau perkembangan kualitas akademis dari anaknya. Dengan begitu secara tidak langsung, orang tua/wali juga membutuhkan akses informasi akademik. Untuk mengakses informasi akademik orang tua/wali membutuhkan sebuah media, media yang dimaksud peneliti di sini adalah penyampaian akses informasi akademik menggunakan telepon genggam/smartphone. Tentu kita ketahui telepon genggam/smartphone sudah menjadi bagian terpenting dalam kehidupan sehari hari. Dengan memanfaatkan smartphone ini, informasi akademi yang relevan dan up to date bagi (stakeholder calon mahasiswa, dosen, mahasiswa, administrasi, pengguna lulusan), di mana saja dan kapan saja [1].

Pembuatan akses informasi akademik tentu membutuhkan media penyimpanan, contoh penyimpanan yang dalam pengaksesannya memerlukan jaringan internet yaitu cloud, atau biasa disebut cloud computing. Informasi akademi yang dibangun memanfaatkan google drive ini, membutuhkan arsitektur teknologi informasi berbasis cloud computing yang sesuai dengan kondisi dan kebutuhan perguruan tinggi di Indonesia[2]. Salah satu pemanfaatan dari cloud computing yaitu dengan memanfaatkan google drive sebagai layanan penyimpanan data. Dengan cara seperti ini diharapkan teknologi yang diterapkan akan menguntungkan[3] dan pelayanan terhadap civitas akademika menjadi lebih baik. 


\section{Metode Penelitian dan implementasi}

\subsection{Cloud Computing}

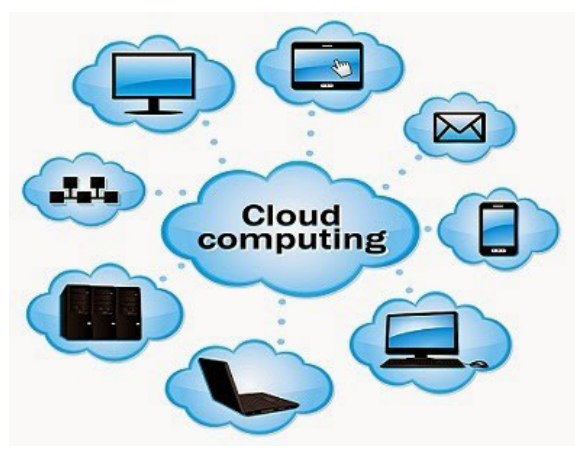

Gambar 1. Cloud computing

(Sumber : http://www.it-jurnal.com/2014/08/ pengertian-cloud-computing.html)

Secara umum, definisi cloud computing (komputasi awan) merupakan gabungan pemanfaatan teknologi komputer (komputasi) dalam suatu jaringan dengan pengembangan berbasis internet (awan) yang mempunyai fungsi untuk menjalankan program atau aplikasi melalui komputer yang terkoneksi pada waktu yang sama, tetapi tak semua yang terkoneksi melalui internet menggunakan cloud computing. Teknologi komputer berbasis sistem cloud ini merupakan sebuah teknologi yang menjadikan internet sebagai pusat server untuk mengelola data dan juga aplikasi penggunaan seperti terlihat pada Gambar 1 .

\subsection{Analisa Sistem}

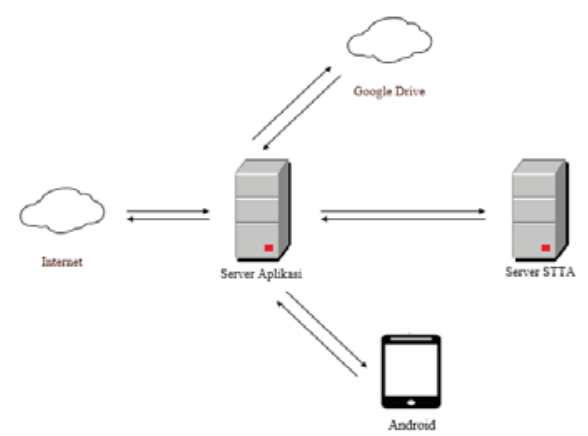

Gambar 2. Skema cloud sistem informasi akademik

Gambar 2. menunjukkan konsep dari aplikasi sistem informasi akademik berbasis cloud yang dibangun. Aplikasi yang digunakan user berbasis android untuk pemanggilan data yang diperlukan, data yang dimaksudkan di sini adalah file $p d f$, dari webserver aplikasi stta-akademik.tk mengakses data ke webserver STTA, sitem dari webserver sttaakademik.tk berfungsi mengunggah file pdf yang di dapat dari webserver STTA lalu file pdf tersebut disimpan secara temporary dan diteruskan ke google drive dan file pdf tersebut dapat dilihat user pada smartphone android yang digunakan.

\subsection{Use Case Diagram}

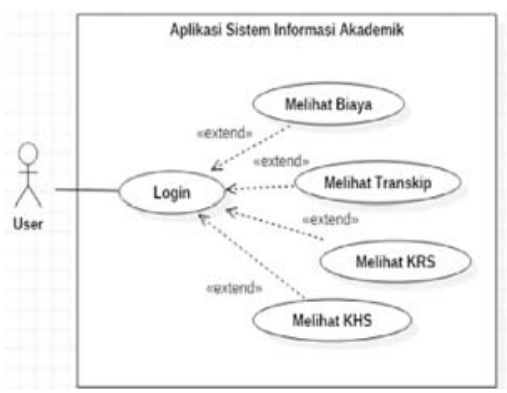

Gambar 3. Use case diagram untuk user

Use case mendeskripsikan interaksi tipikal antara para pengguna sistem dengan sistem itu sendiri, dengan memberi sebuah narasi tentang bagaimana sistem tersebut digunakan. Gambar 3 merupakan use case diagram dari user. Dari gambar tersebut dapat dijelaskan bahwa aktivitas yang dilakukan user terhadap sistem adalah login. Lalu user dapat melihat data biaya, transkip, KRS, dan KHS. Di aplikasi ini juga terdapat menu reset digunakan apabila user salah memasukkan NIM pada saat login.

\subsection{Sequence Diagram}

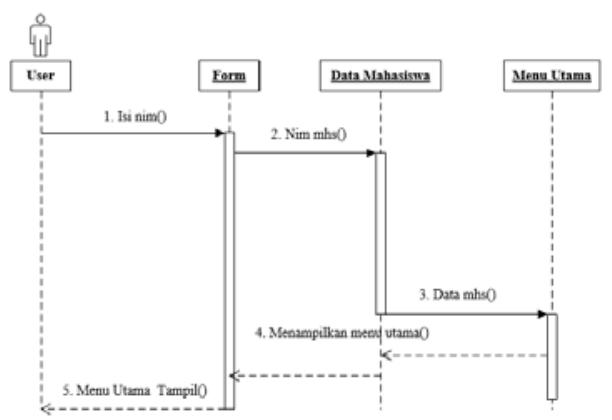

Gambar 4. Sequence diagram login

Pada gambar 4 menjelaskan alur sequence diagram login, user menjalankan aplikasi kemudian muncul form login, lalu user memasukan NIM. 
Sistem akan mengecek apakah NIM yang dimasukkan terdaftar atau tidak. Tapi sistem tetap akan menyimpan NIM yang diinputkan (asumsi panjang NIM lebih dari 5 karakter), setelah itu user dapat masuk ke menu utama.

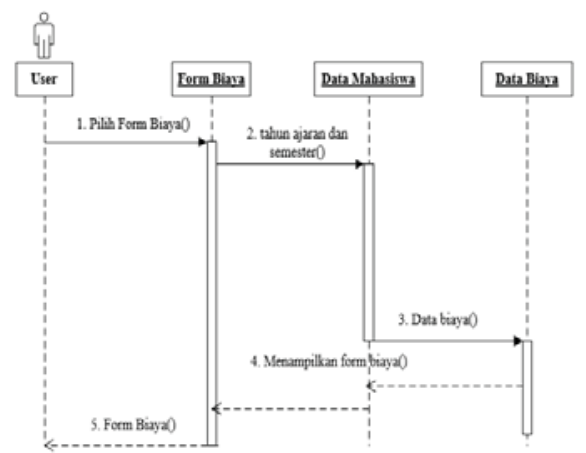

Gambar 5. Seqeunce diagram lihat data biaya

Gambar 5 menjelaskan alur sequence diagram lihat data biaya, user memilih form biaya kemudian user memilih semester dan tahun ajaran. Setelah itu sistem mengakses data dari web server STTA untuk mengambil data biaya dan menyimpannya secara otomatis di google drive lalu ditampilkan pada smartphone android user. Gambar 6 menjelaskan alur sequence diagram lihat data transkip, user memlih form transkip, pada form ini user tidak perlu memilih tahun ajaran dan semester. Setelah itu sistem mengakses data ke webserver STTA untuk mengambil data transkip dan menyimpannya secara otomatis di google drive lalu ditampilkan pada smartphone android user.

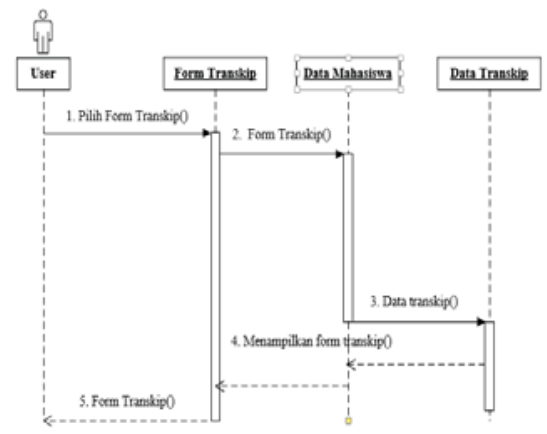

Gambar 6. Sequence diagram lihat transkip

Pada gambar 7 menjelaskan alur sequence diagram lihat data KRS, user memlih form KRS kemudian user memilih semester dan tahun ajaran. Setelah itu sistem mengakses data ke webserver STTA untuk mengambil data KRS dan menyimpannya secara otomatis di google drive lalu ditampilkan pada smartphone android user. Gambar 8 menjelaskan alur sequence diagram lihat data KHS, user memlih form KHS kemudian user memilih semester dan tahun ajaran. Setelah itu sistem mengakses data ke webserver STTA untuk mengambil data KHS dan menyimpannya secara otomatis di google drive lalu ditampilkan pada smartphone android user.

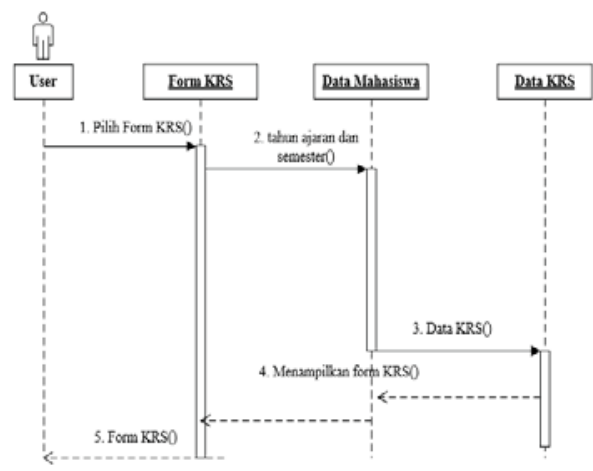

Gambar 7. Sequence diagram lihat KRS

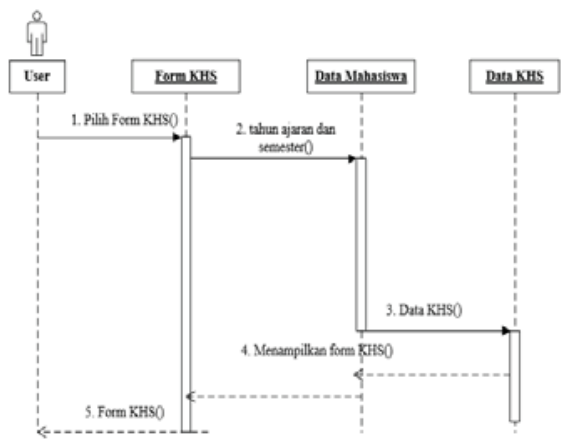

Gambar 8. Sequence diagram lihat KHS

\subsection{Implementasi}

Pada sub bab ini akan dijelaskan tentang fungsi dari halaman-halaman yang terdapat pada aplikasi sistem informasi akademik. Orang tua/wali sebagai user yang menggunakan aplikasi berbasis android, user harus login terlebih dahulu menggunakan NIM anaknya (asumsi panjang NIM lebih dari 5 karakter). Setelah itu user dapat masuk ke halaman utama aplikasi yang berisikan menu utama, dan terdapat snackbar apabila NIM yang dimasukkan salah, user dapat me-reset dan melakukan login ulang, selanjutnya pada menu utama tersebut 
berisikan menu biaya, transkip, KRS dan KHS. Dalam pengimplementasian aplikasi ini, user harus login terlebih dahulu. Form login berfungsi untuk mengautentifikasi NIM yang terdaftar masuk ke sistem. User login dengan menggunakan NIM(asumsi panjang NIM lebih dari 5 karakter). Tampilan halaman login seperti pada gambar 9 .

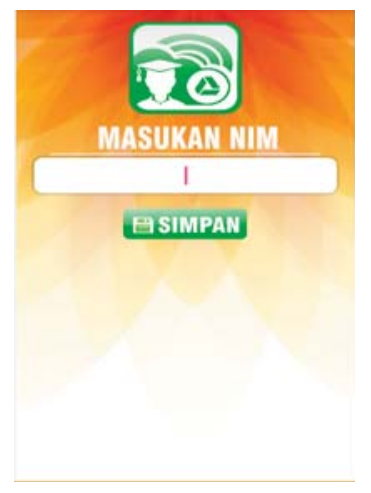

Gambar 9. Form login

Setelah berhasil login, maka user akan masuk ke form menu utama yang merupakan bagian utama dari menu aplikasi yang akan dilihat user setelah berhasil login. Pada halaman ini terdapat beberapa menu utama yaitu biaya, transkrip, KRS, dan KHS. Tampilan halaman utama dari aplikasi sistem informasi akademik seperti pada gambar 10 .

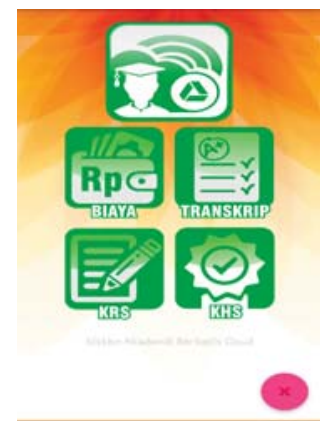

Gambar 10. Form menu utama

Jika menu biaya dipilih, user dapat melihat data biaya namun sebelumnya user harus memilih tahun ajaran dan semester yang diinginkan terlebih dahulu. Setelah memilih tahun ajaran dan semester yang diinginkan. Maka user menekan button pilih. Lalu user dapat melihat data biaya sesuai tahun ajaran dan semester yang telah dipilih sekaligus daftar mata kuliah yang diambil.

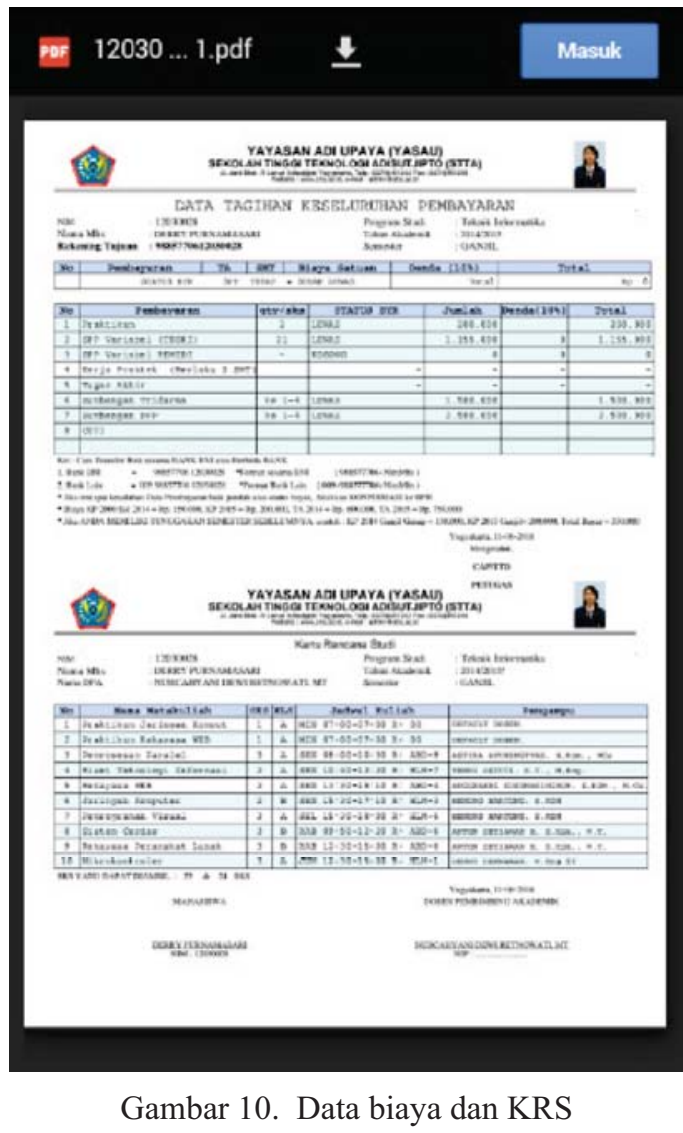

Pada menu KHS, user dapat melihat data KHS namun sebelumnya user harus memilih tahun ajaran dan semester yang diinginkan terlebih dahulu. Setalah itu akan muncul tampilan pemilihan tahun ajaran dan semester seperti pada gambar 11. Jika menu transkip dipilih, maka user tidak perlu lagi memilih tahun ajaran dan semester. Sehingga ketika user memilih menu transkrip, user langsung dapat melihat data transkip secara keseluruhan. Tampilan menu lihat data transkip seperti pada gambar 12 . 


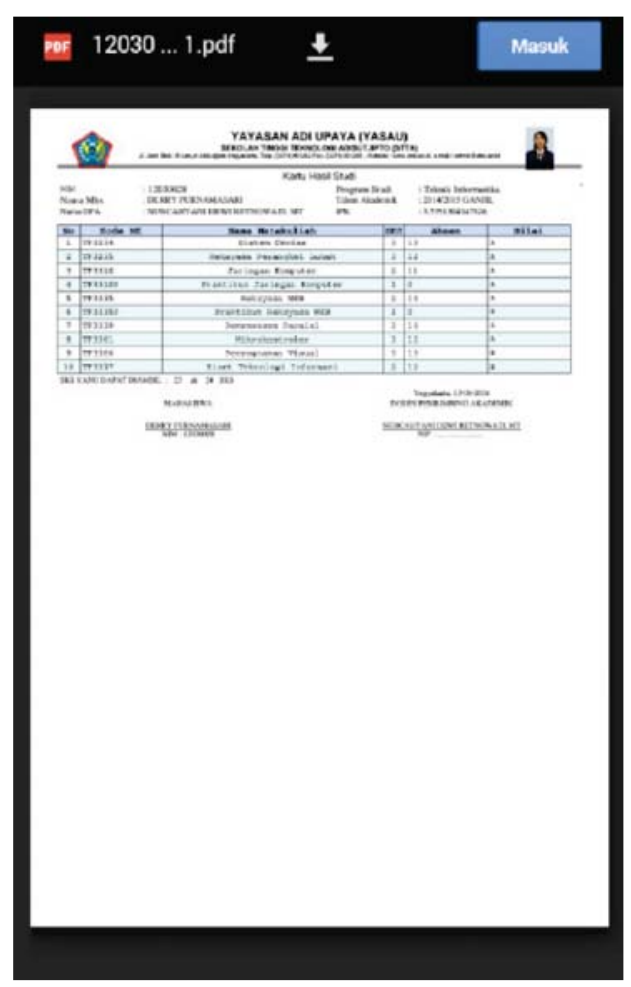

Gambar 11. Data KHS

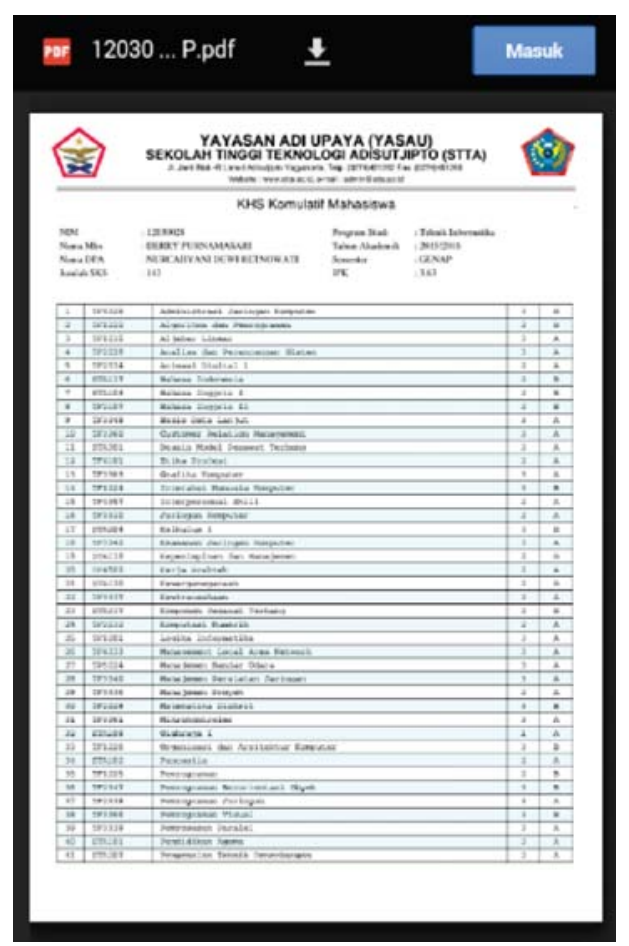

Gambar 12. Data transkrip nilai

\section{Hasil dan Pembahasan}

Lihat gambar 2, gambar tersebut menjelaskan skema aplikasi sistem informasi akademik berbasis cloud. Cara kerja aplikasi ini yaitu orang tua/wali mengakses dari smartphone android dan mengisikan NIM anaknya. Aplikasi ini terdiri dari webserver aplikasi yang dinamakan stta-akademik.tk di mana webserver ini memiliki fungsi untuk mengakses data ke webserver STTA dan meng-upload data akademik lalu disimpan pada cloud storage yaitu google drive, serta aplikasi pendukung berbasis android untuk user untuk melihat data akademik dalam bentuk pdf.

Pada aplikasi ini hanya membahas pemanfaatan google drive sebagi media penyimpanan yang berbasis cloud computing. Pada penyimpannya google drive berfungsi menyimpan data akademik berupa biaya, transkip, KRS dan KRS dalam bentuk pdf, sistem ini berjalan apabila user setelah login ingin melihat data akademik yang diinginkan, maka sistem dari webserver aplikasi akan mengakses data ke webserver STTA dan meng-upload secara otomatis ke google drive, jadi apabila sebelumnya data tersebut belum pernah diakses maka data tersebut belum ada pada google drive. Berikut ini adalah data akademik yang pernah diakses pada aplikasi Sistem Informasi Akademik dan terdapat pada google drive.

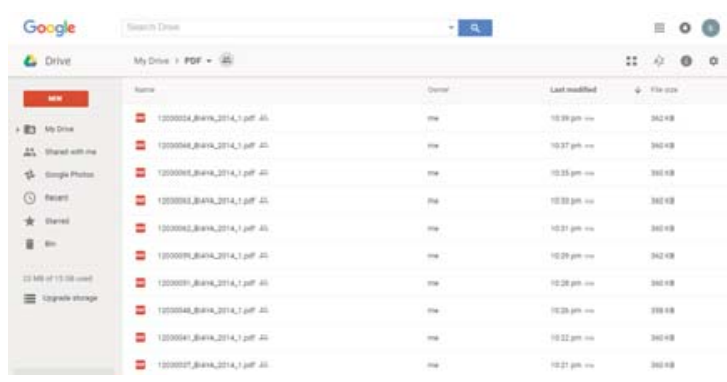

Gambar 13. Data Akademik pada Google Drive

Dari hasil pengujian ini menunjukkan bahwa pemanggilan data biaya dalam bentuk format $p d f$ telah berjalan dengan baik. Data tersebut ada pada server dan juga pada google drive, data biaya yang ada pada google drive sesuai dengan NIM yang pernah diinputkan dan diakses pada smartphone android. Dengan demikian pengujian aplikasi Sistem Informasi Akademik telah berjalan dengan baik dan sebagaimana yang diharapkan. 
Uji coba pengguna aplikasi Sistem Informasi Akademik dilakukan dengan menggunakan kuesioner yang dihitung berdasarkan metode Skala Likert. Dimana setiap pertanyaan memiliki 5 pilihan jawaban, dengan memberikan skor pada setiap jawaban, yaitu jawaban sangat baik (SB) bernilai skor 5, jawaban baik (B) bernilai skor 4, jawaban cukup (C) bernilai skor 3, jawaban kurang (K) bernilai skor 2 dan jawaban sangat kurang (SK) bernilai skor 1. Untuk menentukan interval jarak dari terendah $0 \%$ hingga tertinggi $100 \%$ digunakan rumus (2.1) I = $100 / 5$ (jumlah pilihan jawaban). Sehingga diperoleh hasil interval jarak 20. Dengan demikian kriteria interpretasi berdasarkan intervalnya dapat dilihat pada tabel 1 .

Tabel 1. Interval Penilaian.

\begin{tabular}{|c|c|c|}
\hline Angka & Keterangan & Inisial \\
\hline $0 \%-19,9 \%$ & Sangat Kurang & SK \\
\hline $20 \%-39,9 \%$ & Kurang & K \\
\hline $40 \%-59,9 \%$ & Cukup & C \\
\hline $60 \%-79,9 \%$ & Baik & B \\
\hline $80 \%-100 \%$ & Sangat Baik & SB \\
\hline
\end{tabular}

Pada kuesioner ini terdiri dari 10 pertanyaan mengenai tampilan dan kerja dari sistem. Adapun pertanyaan yang digunakan dalam lembar kuesioner adalah seperti terlihat pada tabel 2 .

Tabel 2. Pertanyaan pada kuesioner.

\begin{tabular}{|l|l|}
\hline $\mathrm{NO}$ & Pertanyaan \\
\hline 1. & $\begin{array}{l}\text { Aplikasi mudah di-install } \text { dan berjalan baik } \\
\text { pada smartphone. }\end{array}$ \\
\hline 2. & Aplikasi mudah untuk digunakan. \\
\hline 3. & Aplikasi mudah untuk dipahami. \\
\hline 4. & Dari segi tampilan interface. \\
\hline 5. & Kecepatan memproses data. \\
\hline 6. & Ketepatan menampilkan data. \\
\hline 7. & Apakah data yang ditampilkan up to date? \\
\hline 8. & $\begin{array}{l}\text { Apakah anda puas dengan penggunaan aplikasi } \\
\text { tersebut? }\end{array}$ \\
\hline 9. & Apakah aplikasi tersebut layak digunakan? \\
\hline 10. & $\begin{array}{l}\text { Apakah aplikasi tersebut dapat membantu } \\
\text { dalam melihat informasi akademik? }\end{array}$ \\
\hline
\end{tabular}

Pada tabel 3 didapat hasil dari persentase dan ratarata pengujian sistem yang sudah dihitung menggunakan metode skala likert, sehingga mempermudah dalam membaca hasil dari uji pengguna. Hasil yang didapat dari pengujian menggunakan kuesioner dan dihitung dengan metode likert adalah $81,57 \%$ yang di dapat dari mencari rata-rata yaitu total persentase dibagi jumlah pertanyaan, maka dapat disimpulkan bahwa pengujian menggunakan kuesioner termasuk dalam kriteria "Sangat Baik" sesuai alur interval penilaian pada tabel 2 .

Tabel 3 Hasil pengujian sistem.

\begin{tabular}{|c|c|c|c|c|c|c|c|}
\hline \multirow{2}{*}{ No } & \multicolumn{5}{|c|}{ Penilaian } & \multirow{2}{*}{ Total Skor } & \multirow{2}{*}{$\%$} \\
\hline & SB & B & C & $\mathbf{K}$ & SK & & \\
\hline 1 & 8 & 18 & 4 & 0 & 0 & 124 & $82,6 \%$ \\
\hline 2 & 6 & 20 & 4 & 0 & 0 & 122 & $81,3 \%$ \\
\hline 3 & 9 & 16 & 5 & 0 & 0 & 124 & $82,6 \%$ \\
\hline 4 & 10 & 19 & 1 & 0 & 0 & 129 & $86 \%$ \\
\hline 5 & 1 & 16 & 13 & 0 & 0 & 108 & $72 \%$ \\
\hline 6 & 4 & 18 & 8 & 0 & 0 & 116 & $77,3 \%$ \\
\hline 7 & 4 & 22 & 12 & 0 & 0 & 120 & $80 \%$ \\
\hline 8 & 8 & 19 & 3 & 0 & 0 & 125 & $83,3 \%$ \\
\hline 9 & 11 & 17 & 2 & 0 & 0 & 129 & $86 \%$ \\
\hline 10 & 8 & 21 & 1 & 0 & 0 & 127 & $84,6 \%$ \\
\hline \multicolumn{7}{|c|}{ Total Persentase } & $815,7 \%$ \\
\hline & & & & Rat: & -rate & & $81,57 \%$ \\
\hline
\end{tabular}

\section{Kesimpulan}

Kesimpulan yang diperoleh dari hasil analisa pengujian aplikasi sistem informasi akademik berbasis cloud adalah sebagai berikut :

1. Google drive dapat digunakan sebagai media penyimpanan dalam Sistem Informasi Akademik berbasis cloud.

2. Mempermudah orang tua/wali dalam mendapatkan informasi akademik dari Smartphone dengan sistem operasi android dan dapat dimanfaatkan oleh orang tua/wali untuk memantau perkembangan kualitas akademik dari anaknya yang mengikuti perkuliahan di STTA Yogyakarta.

3. Data yang ada pada google drive sesuai dengan NIM yang pernah diinputkan dan diakses pada smartphone android.

4. Pengujian menggunakan kuesioner dan dihitung dengan metode skala likert adalah $81,57 \%$, maka dapat disimpulkan bahwa pengujian menggunakan kuesioner termasuk dalam kriteria "Sangat Baik". 


\section{Saran}

Fitur-fitur yang dapat ditambahkan pada aplikasi ini adalah sebagai berikut :

1. Untuk selanjutnya aplikasi Sistem Informasi Akademik berbasis cloud ini tidak hanya dapat diakses orangtua/wali untuk jurusan informatika saja tetapi untuk seluruh mahasiswa STTA Yogyakarta.

2. Level keamanan aplikasi Sistem Infromasi Akademik berbasis Cloud perlu dibahas dan ditingkatkan.

\section{Ucapan Terima kasih}

Penulis mengucapkan terima kasih kepada Sekolah Tinggi Teknologi Adisutjipto Yogyakarta yang telah memberi dukungan finansial terhadap penelitian ini.

\section{DAFTAR PUSTAKA}

Alicia Sinsiuw, Xaverius Najoan, 2013, Prototipe Aplikasi Sistem Informasi Akademik Pada Perangkat Android. E-Journal Teknik Elektro dan Komputer, Universitas Samratulangi, Manado, http://ejournal. unsrat.ac.id/index.php/elekdankom/article/ download $/ 4291 / 3820$
Achmad Solichin, Zainal A. Hasibuan, 2012, Pemodelan Arsitektur Teknologi Informasi Berbasis Cloud Computing Untuk Institusi Perguruan Tinggi Di Indonesia. Universitas Indonesia, http://download.portalgaruda.org/ article.php? article $=113570 \& \mathrm{val}=5187$

Ahmad Ashari, Herri Setiawan, 2011, Cloud Computing : Solusi ICT ? Jurnal Sistem Informasi. (JSI) VOL. 3. NO. 2. Oktober 2011.

Dennis, Alan dkk. 2005. System Analysis Design with UML version 2.0 and Object-Oriented Approach, Wiley, Indiana Univertity.

Eka, I Putu Agus Pratama, 2014, Smart City beserta Cloud Computing dan Teknologi-Teknologi Pendukung Lainnya, INFORMATIKA, Bandung.

Martin Fowler, 2004. UML DISTILLED Edisi 3. Andi. Yogyakarta.

Sadeli, Muhammad, 2014, Toko Buku Online dengan Android, Maxikom, Palembang. 